\title{
Patterns of plasma progesterone, androgen and oestrogen concentrations and in-vitro ovarian steroidogenesis during embryonic diapause and implantation in the mink (Mustela vison)
}

\author{
I. Stoufflet, M. Mondain-Monval*, P. Simon and L. Martinet \\ Département de Physiologie Animale, Institut National de la Recherche Agronomique, \\ 78350 Jouy en Josas, France; and *Fondation de Recherche en Hormonologie, 67 Boulevard Pasteur, \\ 94268 Fresnes, France
}

\begin{abstract}
Summary. Peripheral plasma progesterone concentrations exhibited an increase 10 days before implantation, coinciding with the resumption of blastocyst growth and with a decrease in plasma androgen values (DHA, androstenedione, testosterone). No definite pattern of oestrone was observed and oestradiol concentrations remained undetectable. The production of steroids by dispersed luteal cells showed that the growth of the corpora lutea paralleled that of blastocysts and resulted in hypertrophy followed by hyperplasia of the luteal cell. The production of progesterone in the medium increased with blastocyst size up to implantation; it was enhanced by mink charcoal-treated serum, but prolactin, LH, FSH or a combination of these hormones did not affect the progesterone production, whatever the stage of diapause. DHA and androstenedione secretion increased in the two last stages of blastocyst growth and was enhanced by LH. The conversion of androstenedione and testosterone into oestrone and oestradiol was observed at all stages of embryonic diapause, indicating that corpora lutea contain aromatase activity even at an early stage. The secretion of oestrone was higher than that of oestradiol. The non-luteal tissue contributed up to $50 \%$ of the steroid production; while progesterone and androgen production remained constant, that of oestradiol decreased at the end of the delay period. These results indicated a change in the size and the secretory capacity of the luteal cell related to blastocyst development and implantation. Although progesterone was the main product of the corpora lutea, androgens and oestrogens were also secreted.
\end{abstract}

Keywords: delayed implantation; mink; corpus luteum; steroid hormones; in vivo; in vitro

\section{Introduction}

In mink (Mustela vison), pregnancy is variable in length ranging from 42 to 75 days. Whatever the date of mating which occurs from late February to late March, implantation is never observed before the last days of March. Blastocysts pass into the uterine horns 7-8 days after mating and enter a state of diapause, the duration of which depends upon the date of mating; the later the mating, the shorter the diapause period (Hansson, 1947; Enders, 1952). In the mink, as in other members of the family Mustelidae exhibiting an obligatory period of delayed implantation, the resumption of blastocyst growth followed by implantation is always related to the onset of progesterone secretion (Mead \& Eik-Nes, 1969; Møller, 1973a; Bonnin et al., 1978). Plasma concentrations of progesterone begin to rise 7-10 days before implantation in mink, reach a peak 20 days before parturition, then gradually decrease to basal values (Møller, 1973a; Murphy \& 
Moger, 1977; Allais \& Martinet, 1978; Einarsson, 1985). Although progesterone secretion is followed by termination of the diapause, all attempts to induce implantation by administration of progesterone in ovariectomized mink (Hansson, 1947; Murphy et al., 1983) or to hasten it in intact females (Hammond, 1951; Holcomb, 1967) have failed, suggesting that other steroidal or non-steroidal factors are required. However, injections of the synthetic progestagen, medroxyprogesterone acetate, seem to hasten implantation (Holcomb, 1967; Concannon et al., 1980).

The luteal tissue seems to be the only compartment essential for implantation; in fact, implantation was observed in ovariectomized mink given progesterone and bearing ectopic corpora lutea under the kidney capsule (Murphy et al., 1983). In the ferret, a closely related species which does not exhibit an embryonic diapause, a factor indispensable for implantation is secreted by the luteal tissue between Days 6 and 8 of pregnancy (Wu \& Chang, 1973; Foresman \& Mead, 1978). Ferret luteal tissue has the ability to synthesize androgens and to convert them into oestrogens (Mead \& Swannack, 1980). Although the conversion of testosterone to oestradiol increases between Days 6 and 8 (Mead \& McRae, 1982), oestradiol does not seem to be the luteal factor required for implantation in the ferret. In fact, implantation was not prevented in females treated with antiserum to oestradiol-17 $\beta$ at various times between Days 3 and 13 (Murphy \& Mead, 1976). Furthermore, the inhibition of implantation induced by an aromatase inhibitor given before Day 8 is not reversed by oestradiol (Mead \& McRae, 1982).

In the mink such data are not available. The present study was therefore undertaken to obtain information on the peripheral concentrations of progesterone, androgens and oestrogens during pregnancy and to examine, by in-vitro methods, the luteal and non-luteal ovarian production of steroids during embryonic diapause, resumption of blastocyst growth and implantation.

\section{Materials and Methods}

Animals. Experiments were carried out on 1- or 2-year-old female mink born in the laboratory colony. Females were housed in individual pens under natural conditions of light and temperature. Commercial food and water were available ad libitum.

In-vivo study. Plasma progesterone concentrations were measured throughout pregnancy in 5 groups of females mated at 5 different periods of the breeding season, between 2 and $4(N=5), 6$ and $8(N=7), 9$ and $11(N=8)$, 12 and $15(\mathrm{~N}=7), 17$ and $21(\mathrm{~N}=4)$ March. Embryonic development was determined in 85 females killed or hysterectomized during pregnancy. Before implantation the uterine horns were flushed with saline $(0.9 \%(\mathrm{w} / \mathrm{v}) \mathrm{NaCl})$ and the blastocysts were measured with a calibrated ocular micrometer. Implantation sites were measured with a ruler.

Plasma concentrations of progesterone, dehydroepiandrosterone (DHA), androstenedione, testosterone, oestrone and oestradiol were also measured in 21 (progesterone and androgens: $N=13$; progesterone and oestrogens: $N=8$ ) pregnant females mated between 5 and 12 March. The females were lightly anaesthetized with an i.m. injection of ketamine hydrochloride ( $30 \mathrm{mg} / \mathrm{kg}$ body weight; Imalgène 500 , Mèrieux, Lyon, France). Blood samples were collected with a heparinized syringe by jugular venepuncture from Day 7 after mating, 3-5 times a week.

In-vitro study. Females $(\mathrm{N}=42)$ mated between 2 and 13 March were used. Ovaries and uterine horns were collected after cervical dislocation, or by unilateral ovariectomy and hysterectomy followed, 7 days later, by collection of the remaining ovary and uterine horn after the females were killed. This latter procedure allowed the collection of increased numbers of pregnancy stages. Surgery was performed under halothane anaesthesia (Fluothane, ICI Pharma, Enghien, France) at different periods between 17 March and 4 April. The corpora lutea were dissected from the non-luteal tissue under a binocular dissecting microscope with iridectomy scissors and both were weighed separately. Blastocysts and implantation sites were measured as described above.

Dispersion of luteal cells. The technique was adapted from those described by Sala et al. (1979) and Wada \& Greenwald (1984) for the rat. The corpora lutea were finely minced before incubation in $2.5 \mathrm{ml}$ Medium 199 containing $0.3 \%$ collagenase (type III, $210 \mathrm{IU} / \mathrm{mg}$, Biopro, Strasbourg, France) at $37^{\circ} \mathrm{C}$ for 30 min in a shaking water bath. The medium was then discarded and $2 \mathrm{ml}$ fresh Medium 199 were added. After 90 min incubation, the cells were dispersed by aspiration with a fine Pasteur pipette. After 1 min stabilization, the supernatant containing the cells was removed and saved. Fresh medium $(0.5 \mathrm{ml})$ was added to the sediment. This dispersion was repeated twice. The supernatants were then pooled and centrifuged at $150 \mathrm{~g}$ for $6 \mathrm{~min}$ at room temperature. The cell pellets were washed with $0.5 \mathrm{ml}$ medium, centrifuged again, suspended in $1 \mathrm{ml}$ Medium 199 containing $0.2 \%$ bovine serum albumin and finally filtered through nylon (Pharmacia, Uppsala, Sweden) to eliminate the clumps of endothelial cells. Cell viability 
checked by the trypan blue exclusion method (Tennant, 1964) was always more than $90 \%$. The number of cells was estimated with a haemocytometer and cell size measured under a microscope equipped with an ocular micrometer.

The cell suspension was diluted in Medium 199 containing $0.2 \%$ bovine serum albumin to obtain a final dilution of $10-15 \times 10^{4} \mathrm{cells} / \mathrm{ml}$.

Incubation. Samples $(1 \mathrm{ml})$ of luteal cell suspension were incubated at $37^{\circ} \mathrm{C}$ for $150 \mathrm{~min}$ in a shaking water bath. The non-luteal tissue was minced and incubated in $2 \mathrm{ml}$ medium. In a number of tests cell viability was checked again after incubation by the trypan blue exclusion method. Then the media were snap-frozen and stored at $-20^{\circ} \mathrm{C}$ until assay.

Reliability of the technique. Incubations of aliquants of luteal cells were repeated 3-6 times for tissue from 8 females. The mean variability between assays in the production of progesterone was $6 \%(R=3-10 \%)$.

Addition of a substrate or hormones to the incubation medium. Either serum (10\%) of male mink treated with $0 \cdot 2 \%$ charcoal or 25 -hydroxycholesterol $(25 \mu \mathrm{g} / \mathrm{ml}$, Steraloids, Wilton, NH, USA) was added to the incubation medium of luteal cells, alone or in combination with the following hormones: ovine LH (500 ng/ml; LER-1056-C2), ovine prolactin ( $500 \mathrm{ng} / \mathrm{ml}$; LER-860-2), ovine FSH (250 ng/ml; LER-1976-A2), oestradiol (100 ng/ml; Roussel-UCLAF, Courbevoie, France), androstenedione or testosterone ( $500 \mathrm{ng} / \mathrm{ml}$; Steraloids, USA).

Steroid assays. Using specific radioimmunoassays, the concentrations of steroids in a $1-\mathrm{ml}$ plasma sample or incubation medium were determined. Steroids were purchased from Steraloids. Radioactive steroids were obtained from Radiochemical Centre (Amersham, UK) or CEA (Saclay, France). Merck analytical grade solvents were used without redistillation. Before extraction, radioactive steroids $(500$ c.p.m.) were added to calculate recovery.

Progesterone, oestrone and oestradiol were measured after diethyl ether extraction and separation on Sephadex LH 20 microcolumns according to Caillol et al. (1983).

Androstenedione, DHA and testosterone were measured after diethyl ether extraction and separation on Celite microcolumns (diameter $=6 \mathrm{~mm}$, height $=6 \mathrm{~cm}$; isooctane and isooctane-benzene, 70:30 v/v, as eluants) (Abraham et al., 1970). The different fractions were then dried and androgens were dissolved in $0.5 \mathrm{ml}$ phosphate buffer, $\mathrm{pH} 7 \cdot 25$. Recovery was determined in a $0.2 \mathrm{ml}$ sample. Two samples of $0.1 \mathrm{ml}$ were incubated at $4^{\circ} \mathrm{C}$ with the diluted antiserum for $3 \mathrm{~h}$, then for $2 \mathrm{~h}$ more with the radioactive androgen. Bound and free fractions were separated using a charcoaldextran mixture. The blank values run with each assay were below assay sensitivity. The principal reliability criteria of these assays are shown in Table 1.

Statistical analysis. Data are expressed as means \pm s.e.m. The comparison of the concentrations of plasma hormones in females before, during and after implantation have been carried out by the comparison of the means from related samples after logarithmic transformation, with a two-tailed $t$ test for the paired difference (Table 2). The comparison of the weight of corpora lutea (Fig. 3) and the luteal production of progesterone, androgens and oestrogens (Table 3) have been carried out by analysis of variance, after logarithmic transformation, followed by Duncan's new multiple range test. The number of cells by corpora lutea (Fig. 3) have been compared, after root square transformation, by the same method. Analysis of variance and two-tailed $t$ test were used to compare the production of steroids by luteal cells in presence or absence of a substrate or hormone (Figs 5, 6 and 7). SAS software programmes were used for all the tests.

\section{Results}

In-vivo study

Progesterone concentrations and embryonic growth. In the 31 females mated at different times during the breeding season the plasma concentration of progesterone remained $<1 \mathrm{ng} / \mathrm{ml}$ until 22 March, whatever the date of mating. Then, in the 5 groups the levels rose until mid-April, reaching peak values of $30-50 \mathrm{ng} / \mathrm{ml}$. Thereafter a gradual decrease was observed until parturition (Fig. 1).

Blastocyst diameter did not increase between 6 and $22 \mathrm{March}$; this period of inhibited growth was also the period of low plasma progesterone concentrations (Fig. 2). Then from $22 \mathrm{March}$, when progesterone concentration began to rise, the blastocyst size increased from 400 to $2200 \mu \mathrm{m}$. The largest blastocysts just before implantation were observed from $30 \mathrm{March}$. The first implantation sites were recorded from 31 March when progesterone concentrations exceeded $15 \mathrm{ng} / \mathrm{ml}$. Between 6 and 8 April, 4 females still exhibited unimplanted small blastocysts which would have implanted later or degenerated afterwards.

The 5 groups of females whelped by the same date after pregnancies of $63 \pm 2,57 \pm 2,54 \pm 2$, $51 \pm 2$ and $48 \pm 2$ days, respectively. 


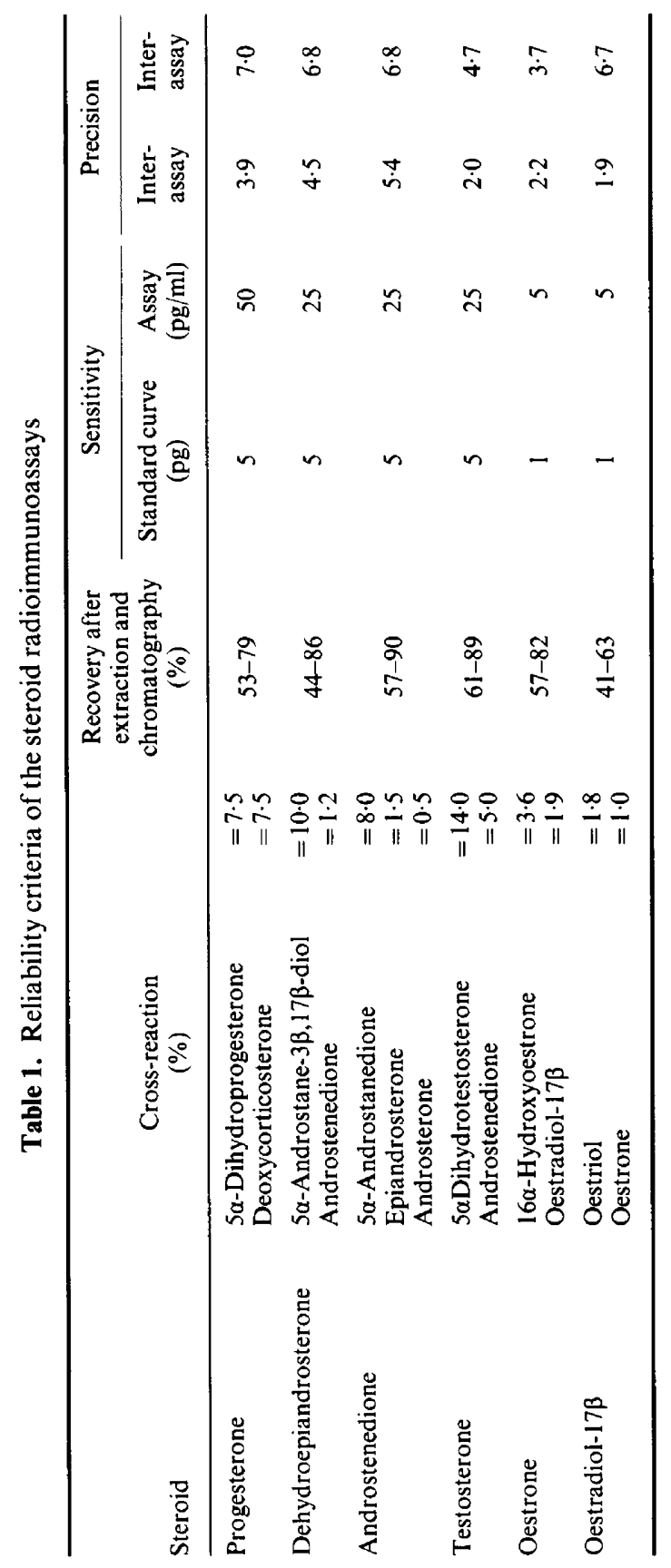




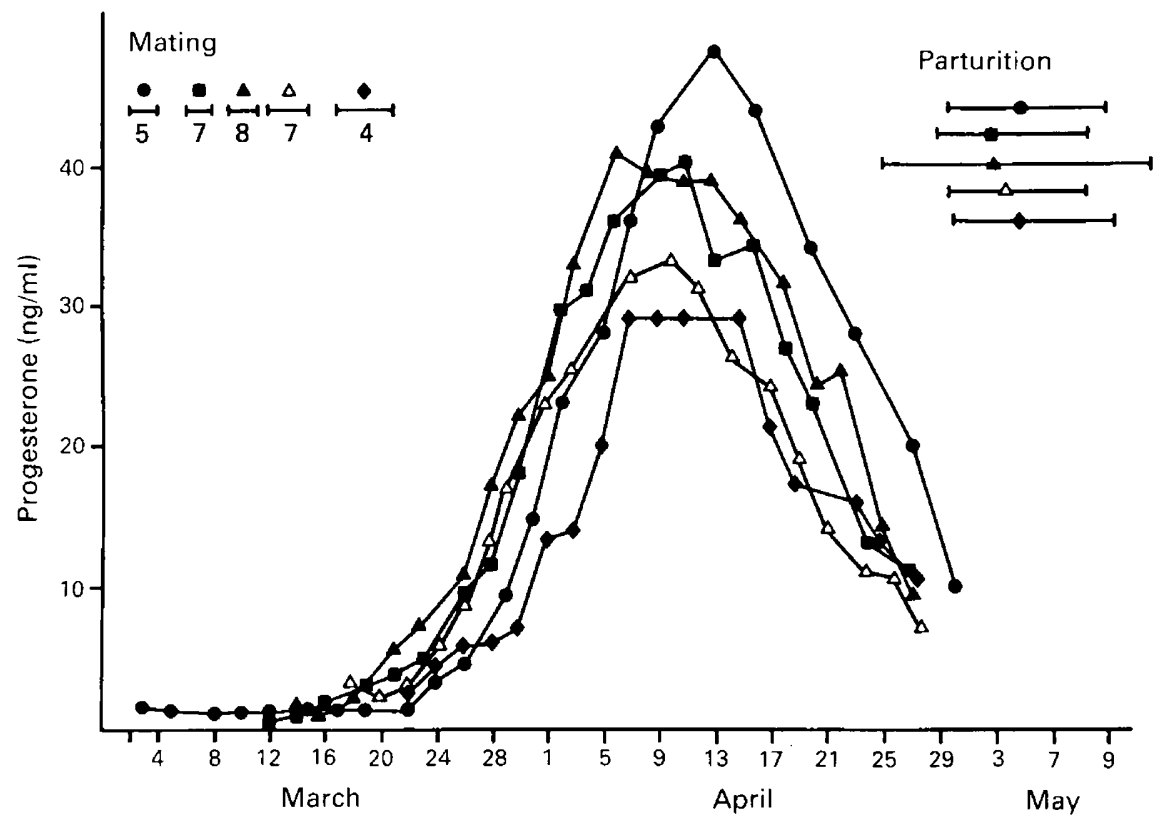

Fig. 1. Patterns of peripheral progesterone concentrations in 31 females mated at 5 different periods of the breeding season. Figures represent the number of animals in each group. The periods of mating and parturition are shown by the horizontal lines.

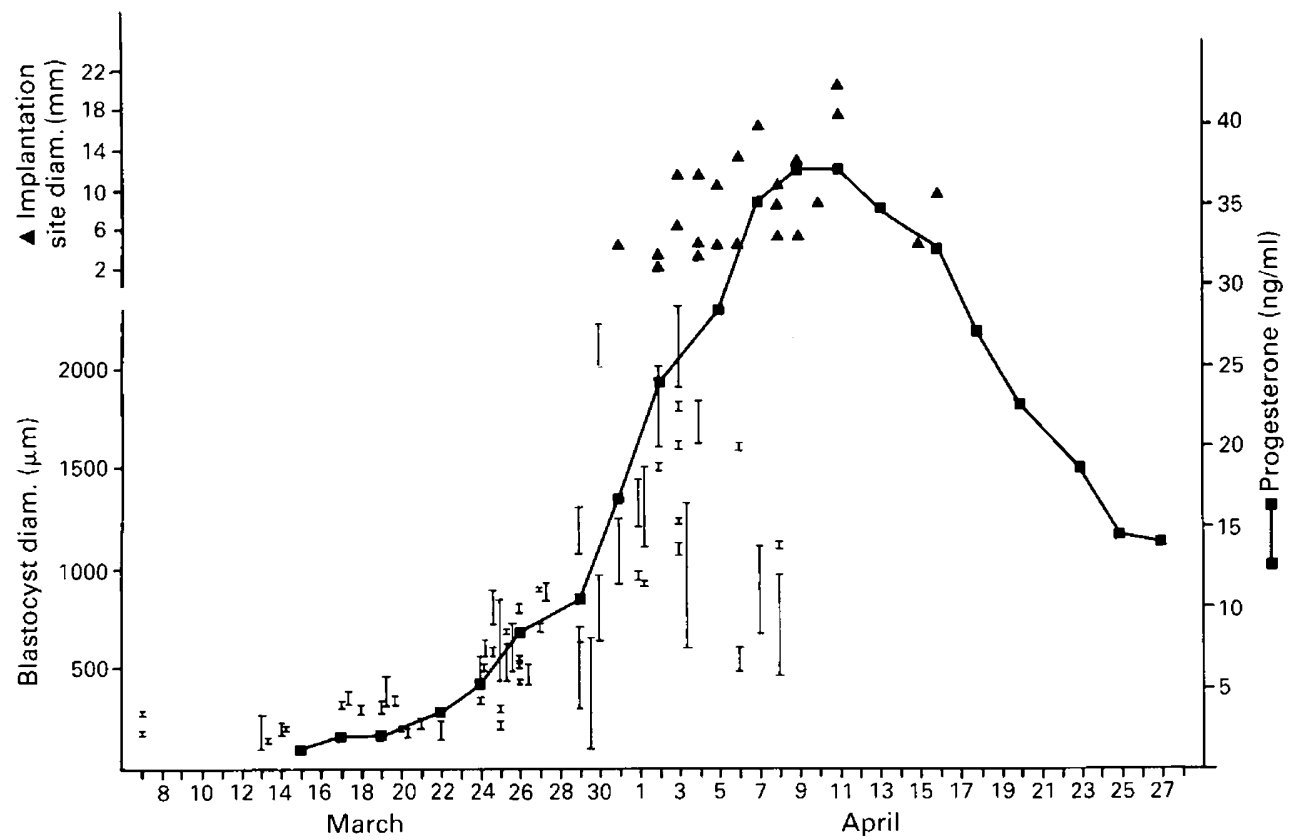

Fig. 2. Blastocyst diameter (vertical lines represent the range for each female), implantation size $(\boldsymbol{\Delta})$ and peripheral progesterone concentration ( $\boldsymbol{G})$ in females mated between 25 February and 15 March. 
Androgen and oestrogen concentrations during pregnancy. In early pregnancy the plasma concentrations of DHA, androstenedione and testosterone were $2 \cdot 1,5 \cdot 7 \mathrm{ng} / \mathrm{ml}$ and $115 \mathrm{pg} / \mathrm{ml}$, respectively. They declined significantly until implantation; then an increase in androstenedione was observed again (Table 2). During the preimplantation and implantation periods, progesterone and androgen concentrations were inversely related. The concentration of oestrone fluctuated from 50 to $150 \mathrm{pg} / \mathrm{ml}$; no definite pattern was observed throughout pregnancy. The concentration of oestradiol was almost always below the detectable level.

Table 2. Plasma concentrations of progesterone, DHA, androstenedione, testosterone and oestrone

\begin{tabular}{|c|c|c|c|c|c|}
\hline $\begin{array}{l}\text { Days before } \\
\text { parturition }\end{array}$ & $\begin{array}{l}\text { Progesterone } \\
\text { (ng/ml) }\end{array}$ & $\begin{array}{l}\text { DHA } \\
(\mathrm{ng} / \mathrm{ml})\end{array}$ & $\begin{array}{l}\text { Androstenedione } \\
\quad(\mathrm{ng} / \mathrm{ml})\end{array}$ & $\begin{array}{l}\text { Testosterone } \\
(\mathrm{pg} / \mathrm{ml})\end{array}$ & $\begin{array}{c}\text { Oestrone } \\
(\mathrm{pg} / \mathrm{ml})\end{array}$ \\
\hline 48 to 38 & $3 \cdot 6 \underset{(51)}{ \pm 0.5}$ & $2 \cdot 10 \underset{(51)}{ \pm 0}$ & $5.66 \frac{ \pm 0.80}{(51)}$ & $115 \underset{(51)}{ \pm}$ & $77 \pm 10$ \\
\hline 35 to 25 & $24 \cdot 1 \pm \frac{2 \cdot 3^{* * *}}{(52)}$ & $0.81 \pm \frac{0.13^{* *}}{(52)}$ & $1.94 \pm \frac{ \pm 0.41^{* *}}{(52)}$ & $64 \underset{(52)}{ \pm} 8^{* *}$ & $\frac{93 \pm 12}{(32)}$ \\
\hline 25 to 8 & $23 \cdot 1 \pm \frac{2 \cdot 6^{* * *}}{(76)}$ & $0.53 \pm \frac{ \pm 0.08 * *}{(76)}$ & $3.87 \pm \frac{0.71^{*}}{(76)}$ & $72 \underset{(76)}{ \pm} 9^{* *}$ & $110 \pm 12$ \\
\hline
\end{tabular}

Values are mean \pm s.e.m. for the no. of samples in parentheses.

Days 48 to 38,35 to 25 and 24 to 8 correspond to the periods of delayed implantation, implantation and postimplantation, respectively.

${ }^{*} P<0.05,{ }^{* *} P<0.01,{ }^{* * *} P<0.001$, compared with concentrations before implantation, i.e. Days 48 to 38 .

\section{In-vitro study}

The variability in duration of the interval between the day of mating and the onset of progesterone increase and resumption of blastocyst growth did not allow chronological dating of the stage of pregnancy from the day of mating. The results were therefore expressed according to the development of the conceptus: 5 stages were defined before implantation according to the mean blastocyst diameter $(<400,400-700,700-1000,1000-1500,>1500 \mu \mathrm{m})$ and 2 after implantation according to the diameter of implantation sites ( $<10 \mathrm{~mm}$ or $10-18 \mathrm{~mm}$ ).

Tissue weights. The increase in the weight of the ovary from $79 \pm 12$ to $177 \pm 23 \mathrm{mg}$ observed during the period of the study resulted from a 6.9-fold and 1.6-fold mean increase in luteal and nonluteal tissue, respectively. The mean weight of corpora lutea slowly increased during the first 3 stages, then significantly from Stage 4 (Fig. 3a). The weight of the non-luteal tissue increased in parallel from $66 \pm 8$ to $107 \pm 14 \mathrm{mg}$.

Luteal cells. The number of cells per corpus luteum did not change from Stages 1 to 4 , but then increased significantly from Stage 5 (Fig. $3 \mathrm{~b}$ ). As the number of cells per $\mathrm{mg}$ did not change except for a transient decrease at Stage 4 (Fig. 3c) the growth of the corpora lutea seems to be due to hypertrophy followed by hyperplasia. Two types of cells were recognized. The small cells $(6-10 \mu \mathrm{m}$ in diameter) represented $95 \%$ of the luteal cells; their number steadily increased from $6.9 \pm 1.4$ (Stage 1) to $32.4 \pm 8.6$ (Stage 7$) \times 10^{4}$ per corpus luteum. The number of large cells $(12-20 \mu \mathrm{m}$ in diameter) increased from Stage 4 (Fig. 3d).

Steroid production. The results are expressed as the final amount of steroids in the incubation medium (tissue + medium), i.e. the production by the luteal or non-luteal tissue per $150 \mathrm{~min}$. The production of progesterone by the corpora lutea increased from $20.4 \pm 7 \cdot 1$ to $179.0 \pm 67.8 \mathrm{ng} /$ $150 \mathrm{~min}$ between Stages 1 and 6. The rate of increase was low during the first 3 stages of blastocyst growth, then became faster before implantation. The production of progesterone by the non-luteal tissue, which was always $<20 \mathrm{ng} / 150 \mathrm{~min}$ represented $50 \%$ of the total production at Stage 1 , and only $20 \%$ at Stages 6 and 7 (Fig. $4 a$ ). 


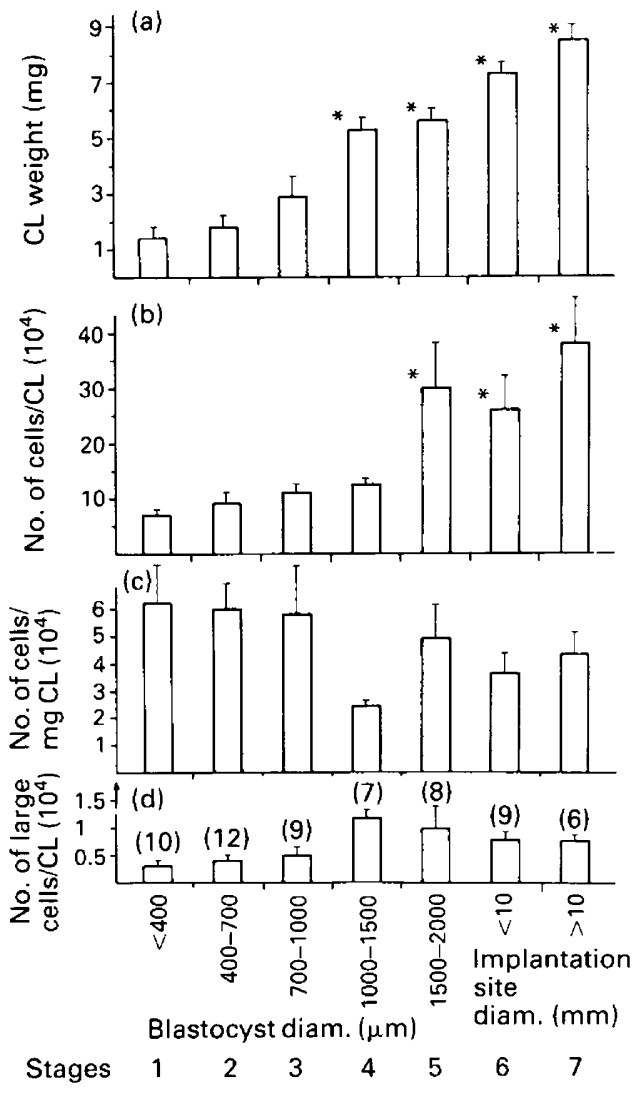

Fig. 3. Patterns of corpus luteum growth during the preimplantation and implantation period in 61 ovaries of pregnant mink. Results are expressed as mean \pm s.e.m. The figures in the bars represent the number of ovaries. (a) ${ }^{*} P<0.05$, Stages $1-3$ compared to Stages $4-5$ and Stages $4-5$ compared to Stages $6-7$. (b) $* P<0.05$, Stages $1-4$ compared to Stages $5-7$.

The production of DHA and androstenedione by the luteal cells progressively increased during the preimplantation period to reach the highest values just after implantation (Table 3). No change in testosterone production was observed. The production of the three androgens by the non-luteal tissue, which did not change throughout the 7 stages of the study, was higher than the production by the luteal tissue, so that the total production by the ovary did not show any clear variation (Fig. 4b, c, d).

A significant increase in the production of oestrone by the luteal tissue was observed (Table 3); the production by the non-luteal tissue, which fluctuated between I and $4 \mathrm{ng} / 150 \mathrm{~min}$, represented around $50 \%$ of the total production (Fig. $4 \mathrm{e}$ ). No variation was observed in the production of oestradiol by the luteal tissue; the non-luteal tissue produced more than $70 \%$ of the total amount. The production by the ovary decreased from $5.3 \pm 1.7$ to $1.9 \pm 0.5 \mathrm{ng} / 150 \mathrm{~min}$ between Stages 1 and 4 , then increased from Stage 5 to 7 (Fig. 4f). The last two stages of blastocyst growth coincided with the lowest production of oestradiol.

Stimulation of luteal steroid production by substrate or hormones. The addition of mink serum to the incubation medium significantly stimulated the production of progesterone during the first phase of blastocyst growth $(P<0.005)$; around implantation the stimulation was reduced. The addition of 25-hydroxycholesterol only induced a significant increase in progesterone production at Stage $3(700-1000 \mu \mathrm{m}$; Fig. 5a, b). Whatever the stage of pregnancy, the hormonal treatments (prolactin, LH, LH + prolactin, FSH, FSH + prolactin, oestradiol, oestradiol + FSH) did not 

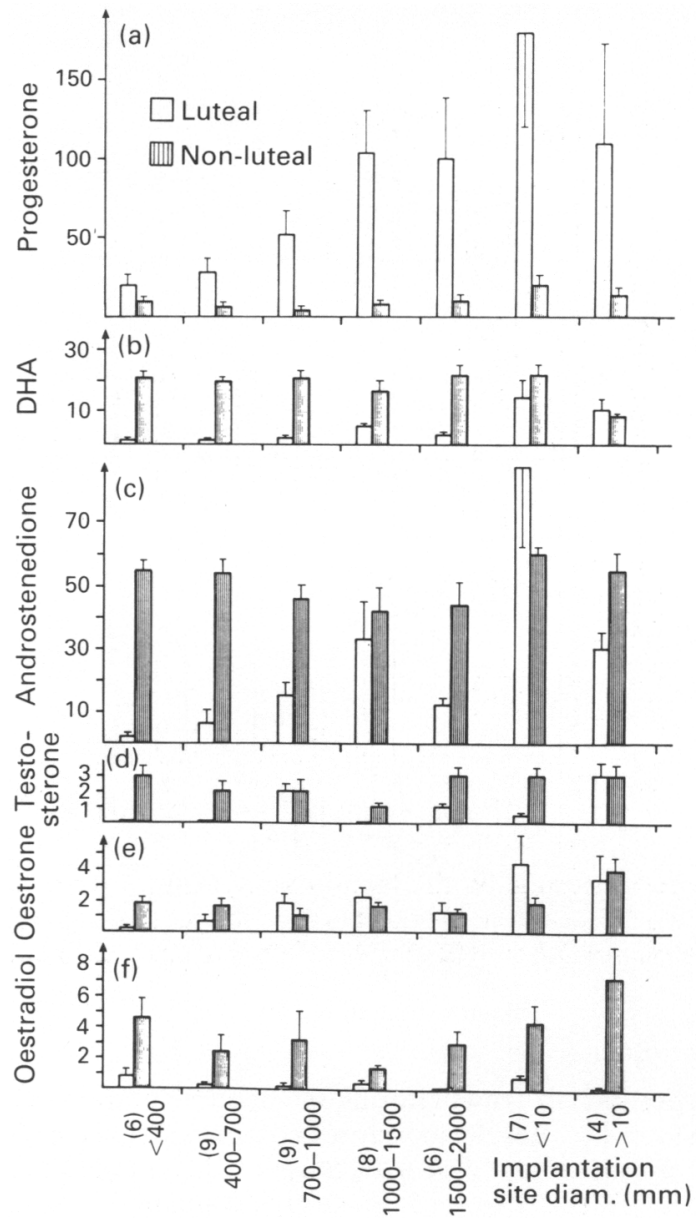

Blastocyst diam. ( $\mu \mathrm{m})$

Fig. 4. Production (ng/150 min) of progesterone (a), DHA (b), androstenedione (c), testosterone (d), oestrone (e) and oestradiol (f) by total luteal and non-luteal tissue. Values are means \pm s.e.m. for the no. of ovaries indicated in parentheses.

Table 3. Production of androgens and oestrogens $(\mathrm{pg} / \mathrm{ml}$ per $150 \mathrm{~min})$ by the corpus luteum of the mink

\begin{tabular}{lccccc}
\hline Stages of pregnancy & DHA & Androstenedione & Testosterone & Oestrone & Oestradiol \\
\hline $1-3$ & $190 \pm 38$ & $1634 \pm 336$ & $78 \pm 50$ & $253 \pm 77$ & $120 \pm 44$ \\
(blastocyst $<1000 \mu \mathrm{m})$ & $(15)$ & $(15)$ & $(15)$ & $(29)$ & $(28)$ \\
4 and 5 & $569 \pm 92^{* *}$ & $2201 \pm 379$ & $159 \pm 62$ & $248 \pm 56$ & $64 \pm 27$ \\
(blastocyst $>1000 \mu \mathrm{m})$ & $(8)$ & $(8)$ & $(8)$ & $(14)$ & $(15)$ \\
6 and 7 & $1615 \pm 377^{* * *}$ & $7777 \pm 2057^{* *}$ & $234 \pm 76$ & $617 \pm 158^{*}$ & $146 \pm 56$ \\
(implantation) & $(10)$ & $(10)$ & $(10)$ & $(15)$ & $(15)$ \\
\hline
\end{tabular}

Values are mean \pm s.e.m. for the number of incubations in parentheses.

${ }^{*} P<0.05,{ }^{* *} P<0.01,{ }^{* * *} P<0.001$, compared to Stages $1-3$. 


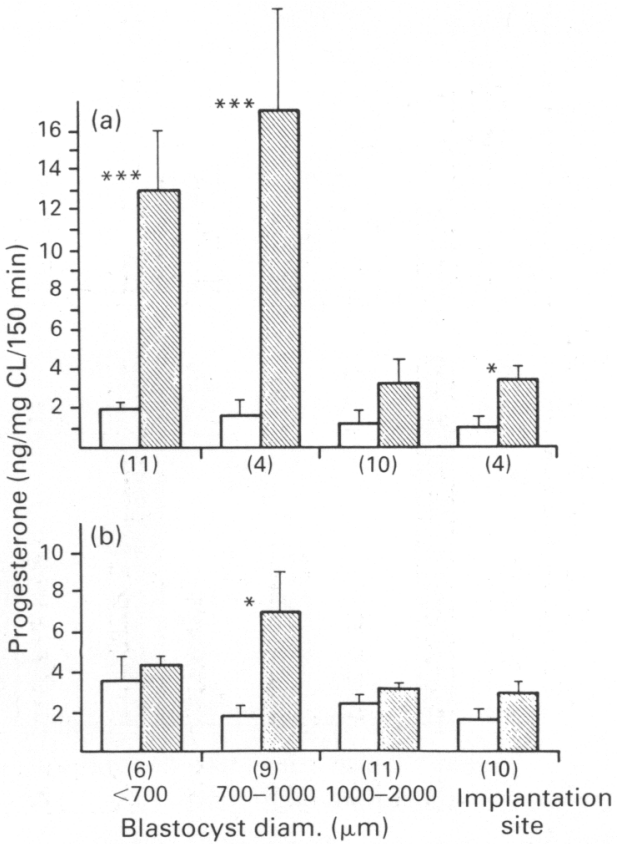

Fig. 5. Production of progesterone by the luteal tissue (mean \pm s.e.m. for the no. of ovaries indicated in parentheses) in the absence (open bars) or the presence (hatched bars) of (a) serum or (b) 25 -hydroxy-cholesterol. ${ }^{*} P<0.05,{ }^{* * *} P<0.005$ compared to control values.
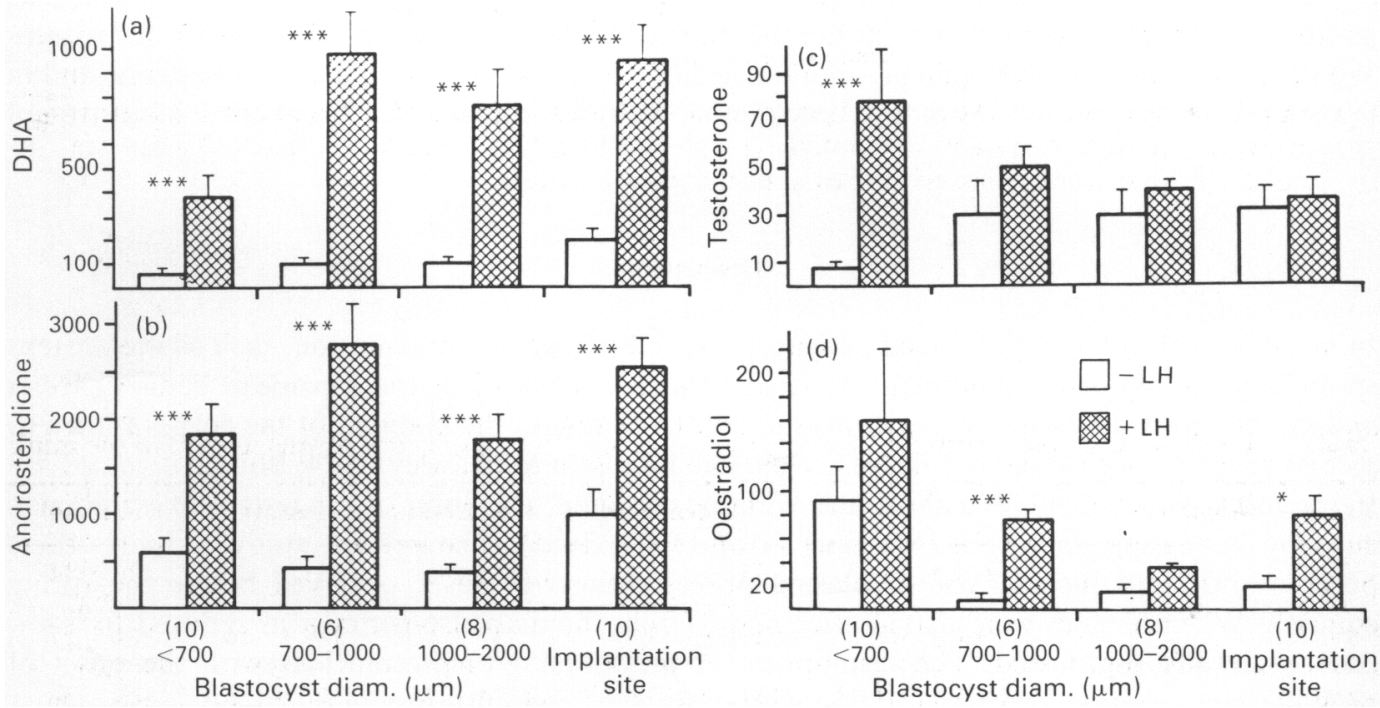

Fig. 6. Production of DHA, androstenedione, testosterone and oestradiol (pg/mg CL/150 min) in the absence or the presence of $\mathrm{LH}$. Values are means \pm s.e.m. for the no. of ovaries indicated in parentheses. ${ }^{*} P<0.05,{ }^{* * *} P<0.005$ compared to control values. 

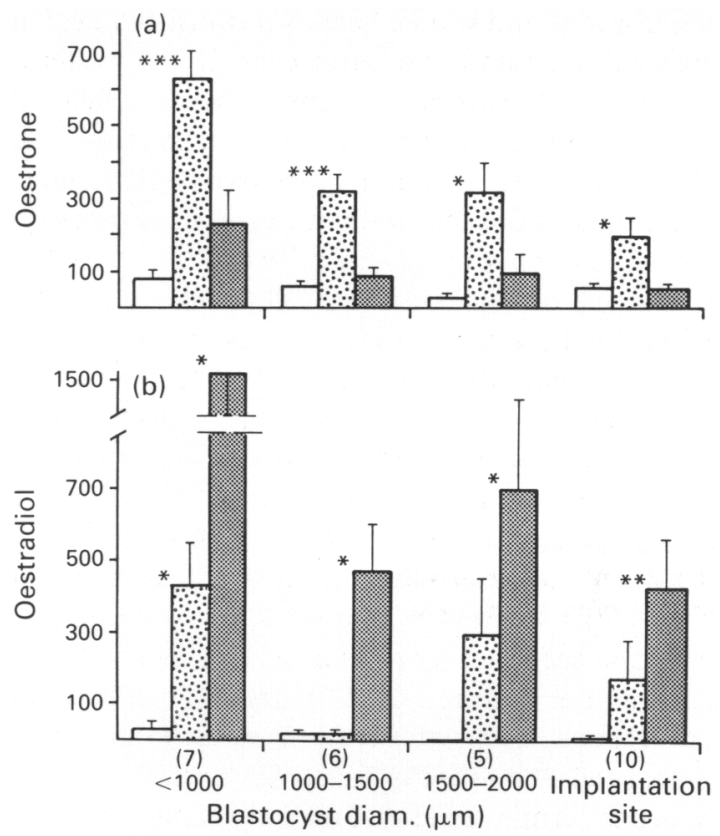

Fig. 7. Production of oestrone and oestradiol (pg/mg CL/150 min) by luteal tissue in the absence (open bars) or the presence of androstenedione (stippled bars) or testosterone (solid bars). Values are means \pm s.e.m. for the no. of ovaries indicated in parentheses. ${ }^{*} P<0 \cdot 05$, ${ }^{* *} P<0.01,{ }^{* * *} P<0.005$ compared to control values.

alter the production of progesterone. Furthermore, the simultaneous addition of hormones to one of the substrates did not modify the increase induced by serum or 25 -hydroxycholesterol. The addition of LH significantly increased the luteal production of the 3 androgens and oestradiol throughout embryonic development (Fig. 6), but had no effect on oestrone production. The addition of androstenedione or testosterone markedly affected luteal production of oestrogens. Whatever the stage of development, androstenedione increased the production of oestrone and in lower proportions that of oestradiol; testosterone mainly stimulated the production of oestradiol (Fig. 7).

\section{Discussion}

In mustelids exhibiting a prolonged obligatory period of delayed inplantation, such as the western spotted skunk (Spilogale putorius), the stoat (Mustela erminea) or the European badger (Meles meles), the arrest in blastocyst growth is thought to be due to the inability of the corpora lutea to secrete progesterone (Mead \& Eik-Nes, 1969; Gulamhusein \& Thawley, 1974; Bonnin et al., 1978). In the mink, which displays a short and variable diapause, the onset of progesterone secretion is cued by increasing daylength (Martinet et al., 1983, 1985). The present study supports these observations since the increase of plasma progesterone was never observed before the spring equinox. When females were mated after mid-March, the diapause period was reduced to a few days or totally suppressed. The resumption of blastocyst growth coincides with the onset of progesterone secretion and implantation with the highest concentration in the blood.

Luteal and non-luteal tissues contributed to progesterone secretion; however, the increase in plasma concentration of progesterone clearly reflected the production by the luteal tissue. The growth of the corpora lutea began by a cellular hypertrophy, previously observed by Møller 
(1973b) on histological preparations and shown here by a transitory decrease in cell number per mg of tissue, and a small increase in the number of large cells. In the western spotted skunk (Sinha \& Mead, 1975) and the ferret (Mustela putorius: Joseph \& Mead, 1988), the small cells appear to differentiate into large cells by the time of implantation. In the mink, the increase in cell size was followed by an increase in cell number; it was not possible to determine whether the increase in number resulted from luteal cell divisions, never observed in other species, or from the luteinization of new cells, as described in the sheep (Schwall et al., 1986).

Neither prolactin, which is luteotrophic in the mink (Papke et al., 1980; Martinet et al., 1981; Murphy et al., 1981), nor LH, FSH or combinations of these hormones increased the production of progesterone. However, after implantation in the mink (Murphy et al., 1984), as in the ferret (McKibbin et al., 1984), prolactin and LH interact with low-density lipoproteins to increase the in-vitro production of progesterone by luteal cells. In our study, the stimulation observed after the addition of mink steroid-free serum to the incubation medium may be due to the lipoprotein-cholesterol complex required for steroid synthesis (Gwynne \& Strauss, 1982), but we did not observe any interaction between the charcoal-treated serum and prolactin or LH. Other components of the serum such as steroid-binding proteins or albumin could be responsible for the stimulation of progesterone secretion as shown by Condon \& Pate (1981) for bovine luteal tissue. The lack of stimulation after addition of 25-hydroxycholesterol may mean that it does not represent an effective steroidogenic substrate for mink luteal tissue, in contrast to the rat (Toaff et al., 1982), or that our luteal cell system is not substrate-limited.

If the relation between progesterone secretion and the resumption of embryonic growth appears clearly, the hormonal requirement for implantation remains as unknown in the mink as it does in other mustelids exhibiting (badger, skunk) or not exhibiting (ferret) a delay in implantation. In the mink, changes in plasma concentrations of oestrone and oestradiol were not observed throughout the embryonic diapause and implantation. Results obtained in other studies are rather contradictory. In the ferret, a slight increase in plasma oestrogens occurs between Day 6 and 8 of pregnancy, i.e. 5 days before implantation (Mead \& McRae, 1982). In the European badger, although episodic releases in oestradiol were reported during the 10-month delay, no variation was observed around implantation (Mondain-Monval et al., 1980). In contrast, in two other species, the mink (Pilbeam et al., 1979) and the spotted skunk (Ravindra \& Mead, 1984), decreasing concentrations of oestradiol or oestrogens were measured in the peripheral blood before implantation. This decrease in oestradiol or androgen (present study) secretion may result from the termination of follicular growth when progesterone secretion begins (Martinet et al., 1981). In the badger, the increase in plasma androgens paralleling that of progesterone was suggested as originating from atretic growing follicles and interstitial gland cells (Mondain-Monval et al., 1983), but in mink the production of androgens by the non-luteal tissue did not increase before implantation. The decrease in plasma androgens did not reflect constant production by the ovary; this discrepancy may result from a change in metabolism throughout pregnancy; it can also be explained by the fact that the blastocyst size does not allow precise dating of the stage of pregnancy.

Our results clearly show that the luteal cell which synthesizes progesterone is also able to produce androgens and convert them into oestrogens. This has already been reported for the corpora lutea of the American badger (Taxidea taxus: Fevold \& Wright, 1969), the ferret (Kintner \& Mead, 1983) and the spotted skunk (Ravindra et al., 1984). However, in contrast to the ferret (Mead \& Swannack, 1980), the luteal tissue of mink produced more oestrone than oestradiol. Furthermore, the production of androgens by the luteal cell was strongly enhanced by $\mathrm{LH}$, as in the rat (Gibori \& Keyes, 1978). The conversion of androgens into oestrogens was observed at all stages, indicating that the early corpus luteum already contains an aromatase activity.

If the corpus luteum is the only compartment essential for implantation (Murphy et al., 1983) and the unknown factor is a steroid, a change in the production of androgens or oestrogens may appear in the course of the embryonic development. In fact an increase in the production of DHA, androstenedione and oestrone was observed during the last two stages of blastocyst growth. 
In ovariectomized mice given progesterone, implantation was obtained with non-aromatizable androgen (Roy et al., 1980), but Mead (1986) was unable to induce implantation in ovariectomized ferrets with progesterone and androstenedione capsules. In contrast, in the mink, the production of oestradiol did not increase before implantation and its stimulation by androstenedione or testosterone was reduced just before implantation. If oestradiol is the missing factor, its production by the corpora lutea may be enhanced in vivo by androgens originating from the non-luteal tissue. However, all attempts to induce implantation with oestradiol have failed in the mink (Cochrane \& Shackelford, 1962), as in the ferret (Mead \& McRae, 1982) and the European badger (Canivenc \& Laffargue, 1958). In fact, Cochrane \& Shackelford (1962) found that oestrone actually prolonged the period of gestation and thus, presumably, the period of embryonic diapause. A role of the non-luteal tissue in the control of implantation cannot be totally discarded; during all of the delay period and during implantation, androgens and oestrogens are secreted by this compartment which contains growing follicles and interstitial tissue in the early stages, then almost exclusively interstitial cells when progesterone secretion by the luteal tissue has begun (Martinet et al., 1981). The typical steroid-secreting nature of the interstitial gland was acknowledged by Møller (1973c), but he did not observe any structural changes associated with physiological states.

The characterization of a protein secreted by the corpus luteum of the ferret and able to induce implantation in ovariectomized females treated with progesterone strongly suggests that the luteal factor required for implantation is not a steroid (Mead et al., 1988). Nevertheless, oestrogens probably participate in the process of implantation by preparing the uterine horns.

This work was supported by grants to I.S. from the Fondation de France, the Fondation de Recherche en Hormonologie and the Chambre d'Agriculture. We thank Dr J. Adeline (FRH, Fresnes) for antisera to androgens; Roussel UCLAF for antisera to oestrogens; R. Monnerie for technical assistance and J. F. Alkombre for animal care.

\section{References}

Abraham, G.E., Tulchinsky, D. \& Korennan, S. (1970) Chromatographic purification of estradiol-17 $\beta$ for use in radio-ligand assay. Biochem. Med. 3, 365-368.

Allais, C. \& Martinet, L. (1978) Relation between daylight ratio, plasma progesterone levels and timing of nidation in mink (Mustela vison). J. Reprod. Fert. 54, 133-136.

Bonnin, M., Canivenc, R. \& Ribes, C. (1978) Plasma progesterone levels during delayed implantation in the European badger (Meles meles). J. Reprod. Fert. 52, 55-58.

Caillol, M., Dauphin-Villemant, C. \& Martinet, L. (1983) Oestrus behaviour and circulating progesterone and oestrogen levels during pseudopregnancy in the domestic rabbit. J. Reprod. Fert. 69, 179-186.

Canivenc, R. \& Laffargue, M. (1958) Action de differents équilibres hormonaux sur la phase de vie libre de l'oeuf fécondé chez le blaireau européen (Meles meles). C. r. Séanc. Soc. Biol. 152, 58-61.

Cochrane, R.L. \& Shackelford, R.M. (1962) Effects of exogenous oestrogen alone and in combination with progesterone on pregnancy in intact mink. J. Endocr. 25, 101-106.

Concannon, P.W., Pilbeam, T. \& Travis, H.F. (1980) Advanced implantation in mink (Mustela vison) treated with medroxyprogesterone acetate during early embryonic diapause. J. Reprod. Fert. 58, 1-6.

Condon, W.A. \& Pate, J.L. (1981) Influence of serum and its lipoprotein fractions on progesterone synthesis and secretion by bovine luteal tissue in vitro. Biol. Reprod. 25, $950-957$.

Einarsson, E.J. (1985) The time of increase in plasma progesterone during pregnancy in mink (Mustela vison). Theriogenology 24, 375-383.

Enders, R.K. (1952) Reproduction in the mink (Mustela vison). Proc. Am. Phil. Soc. 96, 691-755.

Fevold, H.R. \& Wright, P.L. (1969) Steroid metabolism by badger (Taxidea taxus) ovarian tissue homogenates. Gen. comp. Endocr. 13, 60-67.

Foresman, K.R. \& Mead, R.A. (1978) Luteal control of nidation in the ferret (Mustela putorius), Biol. Reprod. 18, 490-496.

Gibori, G. \& Keyes, P.L. (1978) Role of intraluteal estrogen in the regulation of the rat corpus luteum during pregnancy. Endocrinology 102, 1176-1182.

Gulamhusein, A.P. \& Thawley, A.R. (1974) Plasma progesterone levels in the stoat. J. Reprod. Fert. 36, $405-408$.

Gwynne, J.T. \& Strauss, J.F., III (1982) The role of lipoproteins in steroidogenesis and cholesterol metabolism in steroidogenic glands. Endocr. Rev. 3, 299-329.

Hammond, J. (1951) Failure of progesterone treatment to affect delayed implantation in mink. J. Endocr. 7, $330-334$.

Hansson, A. (1947) The physiology of reproduction in mink (Mustela vison) with special reference to delayed implantation. Acta zool., Stockh. 28, 1-136. 
Holcomb, L.C. (1967) Effects of progesterone treatments on delayed implantation in mink. Ohio J. Sci. 67, 24-31.

Joseph, M.M. \& Mead, R.A. (1988) Size distribution of ferret luteal cells during pregnancy. Biol. Reprod. 39, 1159-1169.

Kintner, P.J. \& Mead, R.A. (1983) Steroid metabolism in the corpus luteus of the ferret. Biol. Reprod. 29, $1121-1127$.

Martinet, L., Allais, C. \& Allain, D. (1981) The role of prolactin and $\mathbf{L H}$ in luteal function and blastocyst growth in mink (Mustela vison). J. Reprod. Fert., Suppl. 29, 119-130.

Martinet, L. Allain, D. \& Meunier, M. (1983) Regulation in pregnant mink (Mustela vison) of plasma progesterone and prolactin concentrations and regulation of onset of spring moult by daylight and melatonin injections. Can. J. Zool. 61, 1959-1963.

Martinet, L., Allain, D. \& Chabi, Y. (1985) Pineal denervation by cervical sympathic ganglionectomy suppresses the role of photoperiod on pregnancy or pseudopregnancy, body weight and moulting periods in the mink (Mustela vison). J. Endocr. 107, 31-39.

McKibbin, P.E., Rajkumar, K. \& Murphy, B.D. (1984) Role of lipoproteins and prolactin in luteal function in the ferret. Biol. Reprod. 30, 1160-1166.

Mead, R.A. (1986) Role of the corpus luteum in controlling implantation in mustelid carnivores. Ann. N.Y. Acad. Sci. 476, 25-35.

Mead, R.A. \& Eik-Nes, K.B. (1969) Seasonal variation in plasma levels of progesterone in western forms of the spotted skunk. J. Reprod. Fert., Suppl. 6, 397-403.

Mead, R.A. \& McRae, M. (1982) Is estrogen required for implantation in the ferret? Biol. Reprod. 27, 540-547.

Mead, R.A. \& Swannack, A. (1980) Aromatase activity in corpora lutea of the ferret. Biol. Reprod. 22, 560-565.

Mead, R.A., Joseph, M.M., Neírinckx, S. \& Berria, M. (1988) Partial characterization of a luteal factor that induces implantation in the ferret. Biol. Reprod. 38, 798-803.

Møller, O.M. (1973a) The progesterone concentrations in the peripheral plasma of the mink (Mustela vison) during pregnancy. $J$. Endocr. 56, 121-132.

Moller, O.M. (1973b) The fine structure of the lutein cells in the mink (Mustela vison) with special reference to the secretory activity during pregnancy. $Z$. Zellforsch. mikrosk. Anat. 138, 523-544.

Moller, O.M. (1973c) The fine structure of the ovarian interstitial gland cells in the mink, Mustela vison. $J$. Reprod. Fert. 34, 171-174.

Mondain-Monval, M., Bonnin, M., Canivenc, R. \& Scholler, R. (1980) Plasma estrogen levels during delayed implantation in the European badger (Meles meles). Gen. comp. Endocr. 41, 143-149.

Mondain-Monval, M., Bonnin, M., Scholler, R. \& Canivenc, R. (1983) Plasma androgen patterns during delayed implantation in the European badger (Meles meles). Gen. comp. Endocr. 50,67-74.

Murphy, B.D. \& Mead, R.A. (1976) Effects of antibodies to oestrogens on implantation in ferrets. $J$. Reprod. Fert. 46, 261-263.
Murphy, B.D. \& Moger, W.H. (1977) Progestins of mink gestation: the effects of hypophysectomy. Endocr. Res. Commun. 4, 45-60.

Murphy, B.D., Concannon, P.W., Travis, H.F. \& Hansel, W. (1981) Prolactin: the hypophyseal factor that terminates embryonic diapause in mink. Biol. Reprod. 25, 487-491.

Murphy, B.D., Mead, R.A. \& McKibbin, P.E. (1983) Luteal contribution to the termination of preimplantation delay in mink. Biol. Reprod. 28, 497-503.

Murphy, B.D., Rajkumar, K. \& Silversides, D.W. (1984) Luteotrophic control of the mink corpus luteum during the postimplantation phase of gestation. Proc. 3rd Int. Sci. Cong. Fur Anim Prod., Versailles, 32, 1-8.

Papke, R.L., Concannon, P.W., Travis, H.F. \& Hansel, W. (1980) Control of luteal function and implantation in the mink by prolactin. J. Anim. Sci. 50, 1102-1107.

Pilbeam, T.E., Concannon, P.W. \& Travis, H.F. (1979) The annual reproductive cycle of mink (Mustela vison). J. Anim. Sci. 48, 578-584.

Ravindra, R. \& Mead, R.A. (1984) Plasma estrogen levels during pregnancy in the western spotted skunk. Biol. Reprod. 30, 1153-1159.

Ravindra, R., Bhatia, K. \& Mead, R.A. (1984) Steroid metabolism in corpora lutea of the western spotted skunk (Spilogale putorius latifrons). J. Reprod. Fert. 72, 495-502.

Roy, S.K., SenGupta, J. \& Manchanda, S.K. (1980) Induction of implantation by androgens in mice with delayed implantation. J. Reprod. Fert. 58, 339-343.

Sala, G.B., Dufau, M.L. \& Catt, K.J. (1979) Gonadotropin action in isolated ovarian luteal cells. J. biol. Chem. 254, 2077-2083.

Schwall, R.H., Gamboni, F., Mayan, M.H. \& Niswender, G.D. (1986) Changes in the distribution of sizes of ovine luteal cells during the estrous cycle. Biol. Reprod. 34, 911-918.

Sinha, A.A. \& Mead, R.A. (1975) Ultrastructural changes in granulosa lutein cells and progesterone levels during preimplantation, implantation and early placentation in the western spotted skunk. Cell Tissue Res. 164, 179-192.

Tennant, R.J. (1964) Evaluation of the trypan blue technique for determination of cell viability. Transplantation 2, 685-694.

Toaff, M.E., Schleyer, H. \& Strauss, J.F., III (1982) Metabolism of 25-hydroxycholesterol by rat luteal mitochondria and dispersed cells. Endocrinology 111, 1785-1790.

Wada, Y. \& Greenwald, G.S. (1984) Comparison of in vitro production of progestagens by the corpora lutea of early pregnancy of the rat and hamster. J. Reprod. Fert. 71, 149-154.

Wu, J.T. \& Chang, M.C. (1973) Hormonal requirement for implantation and embryonic development in the ferret. Biol. Reprod. 9, 350-355.

Received 29 December 1988 